تأثير النحاس وحامض السالسيلك في اكتساب المقاومة الجهازية في نباتات الفاصوليا لوقايتها من

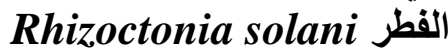

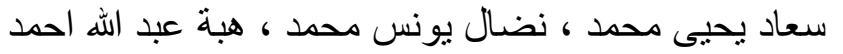

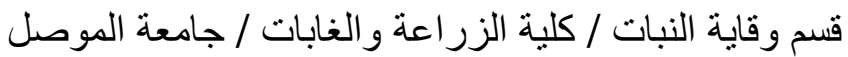

\section{الخلاصة}

هدفت هذه الدراسة الى تقييم المقاومة الجهازية لنباتات الفاصوليا المصابة بتعفن البذور

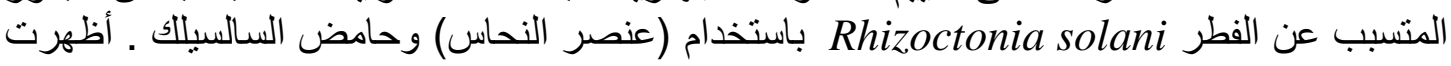

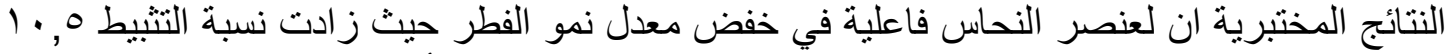

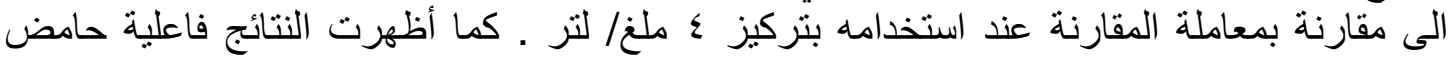

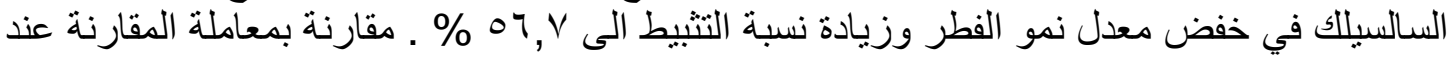

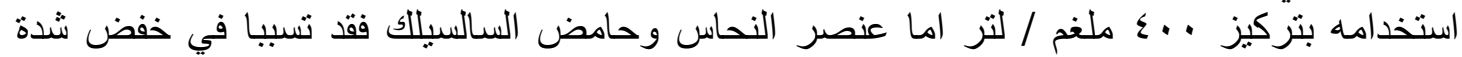

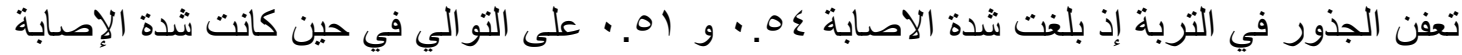

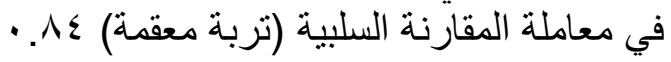

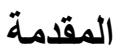

يعد الفطر Rhizoctonia solani من الفطريات المستوطنة في التربة وينمو في مدى واسع

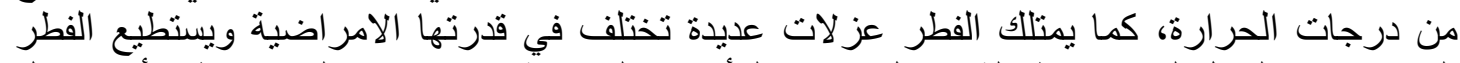

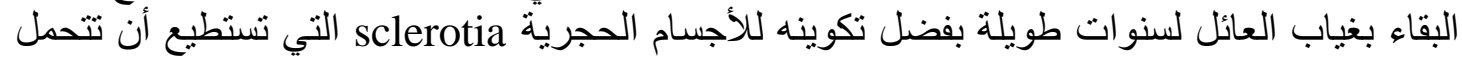

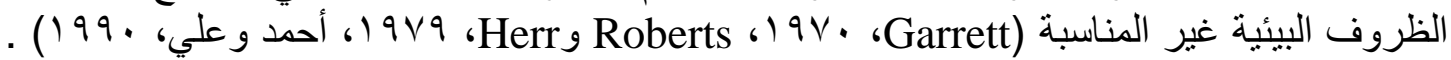

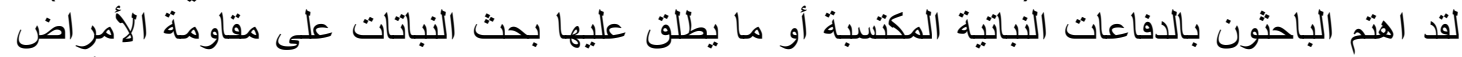

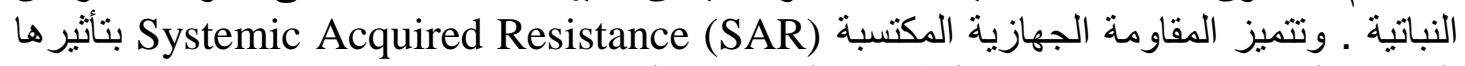

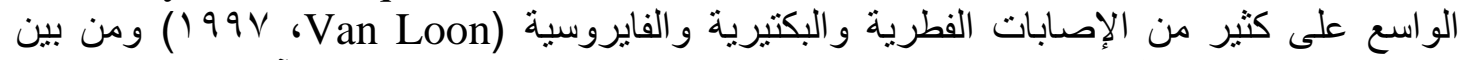

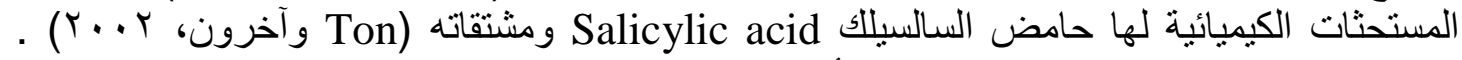

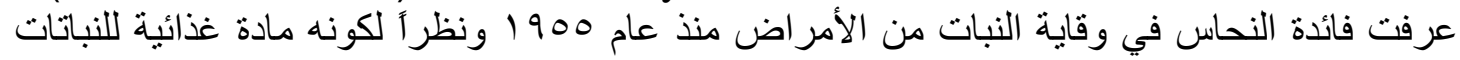

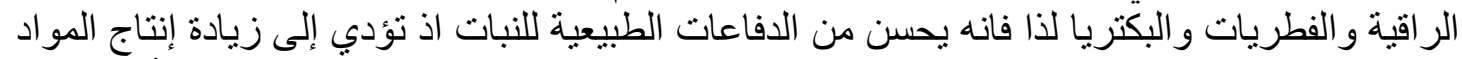

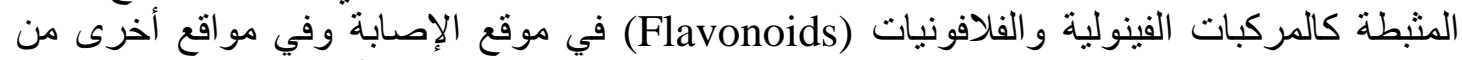

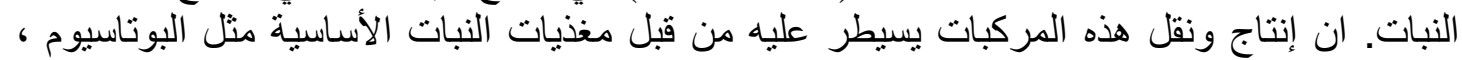

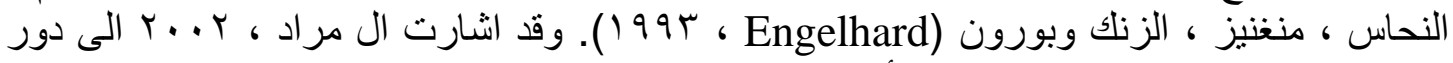

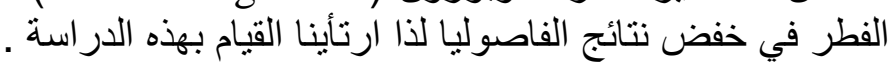

\section{مواد البحث وطرائقه}

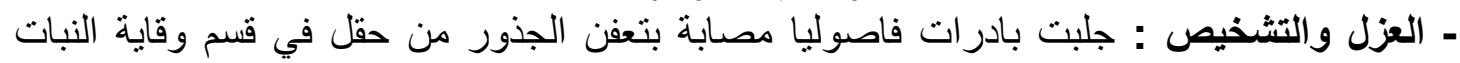

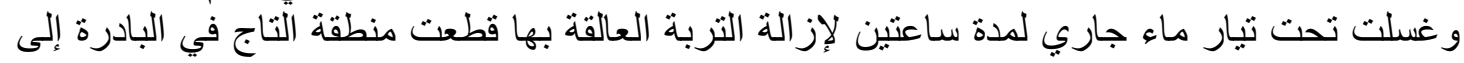

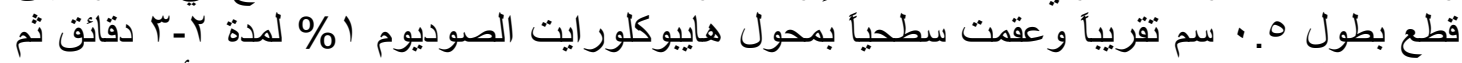

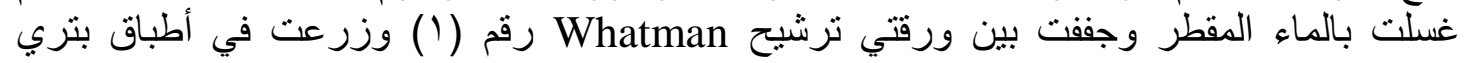

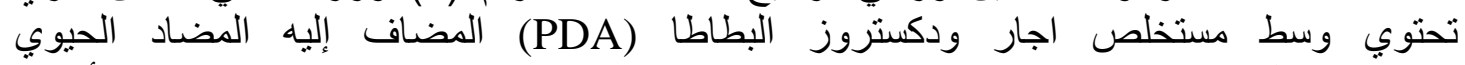

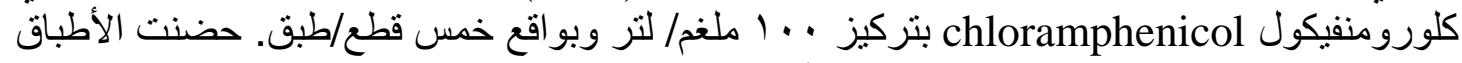

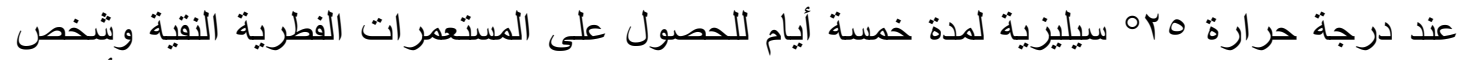

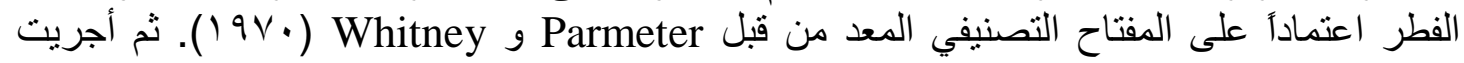
عملية التنقية من العزل بطريقة طرف العن الهايفا النامي.

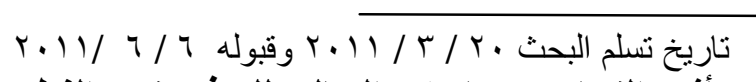

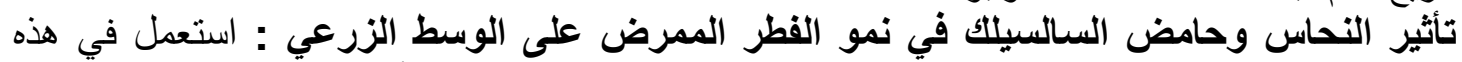

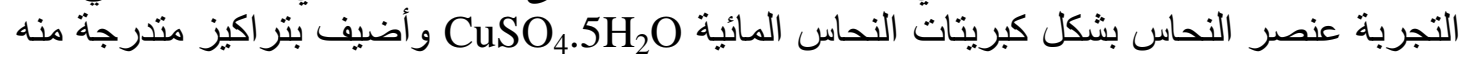




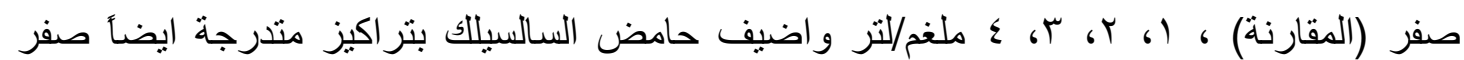

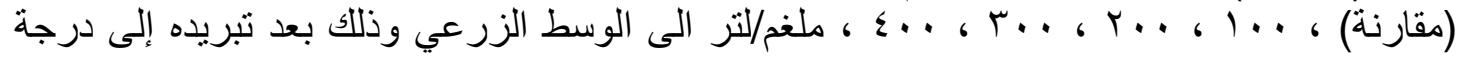

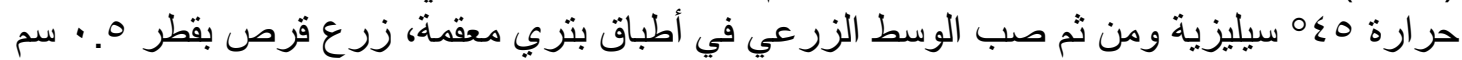

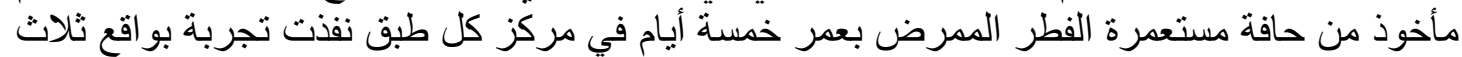

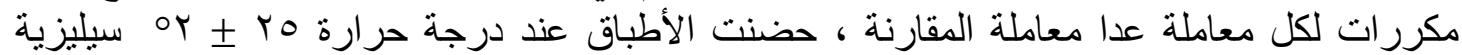

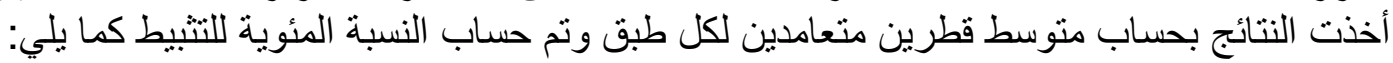

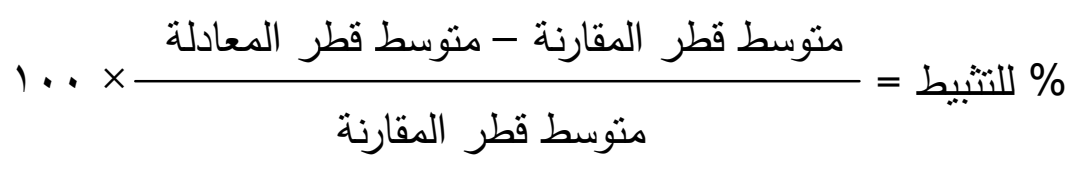

تأثثر عنصر التحاس وحامض السالسيلك في مكافحة الفطر على بادرات الفاصوليا في الظلة البلاستيكية

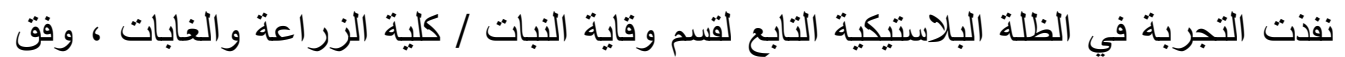

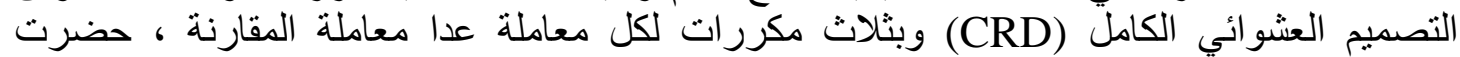

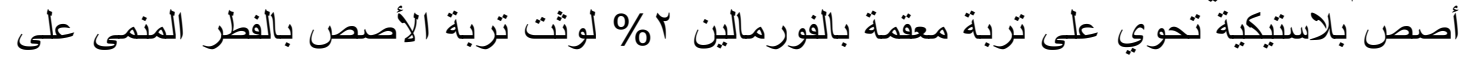

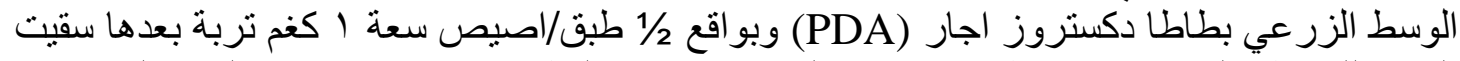

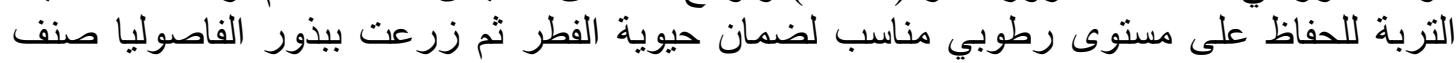

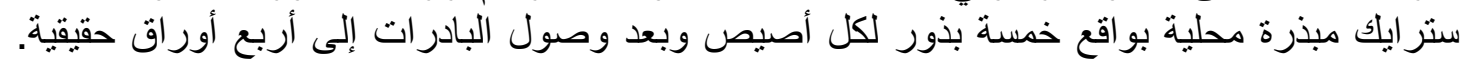

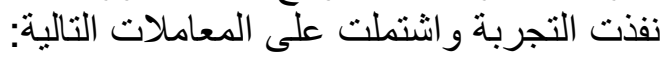

1 - تربة معقمة (معاملة المقارنة)

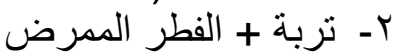

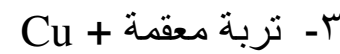

SA + ك - تربة معقمة

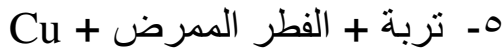

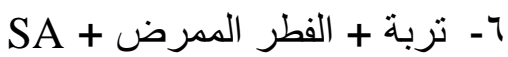

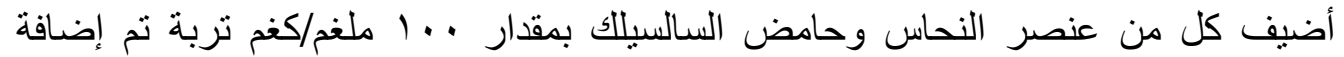

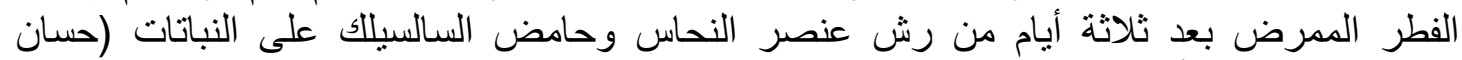

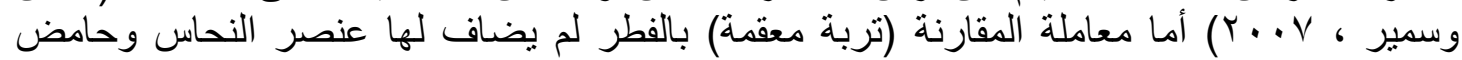

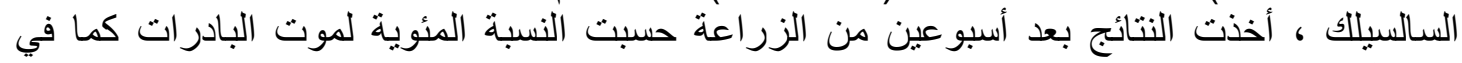

$$
\text { \% نالية: }
$$

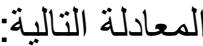

وبعد اب يوم من المعاملة حسبت شدة الإصـابة باستخدام الدليل المرضي المؤلف من

\begin{tabular}{|c|c|}
\hline \multicolumn{2}{|c|}{ Rhizoctonia الجدول ( ) الدليل المرضي للفطر } \\
\hline طبيعـة النبـات & درجة الإصسابة \\
\hline نبات سليم & 1 \\
\hline بقع صغيرة على الجذر أو الساق (0. •- ا سم) & r \\
\hline بقع كبيرة على الجذر أو الساق ( - فأكثر سم) & $r$ \\
\hline موت بعد البزوغ & $\varepsilon$ \\
\hline موت قبل البزوغ & 0 \\
\hline
\end{tabular}

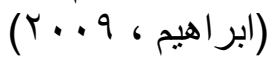

وحسبت شدة الإصابة وفق المعادلة التالية:

مجموعة النباتات من الفئة (1) × دليلها المرضي + ... مجموع النباتات من الفئة (0) × دليلها المرضي 
حللت النتائج إحصائياً واختبرت المتوسطات بطريقة دنكن متعدد الحدود

\section{النتائج والمناقشة}

العزل والتشخيص : أظهرت نتائج العزل في نبات الفاصوليا المصابة بالذبول عن إصابتها باتها بالفطر Rhizoctonia solani kuhn. لون المستعمرة الى اللون البني

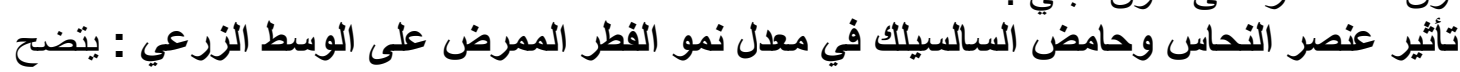

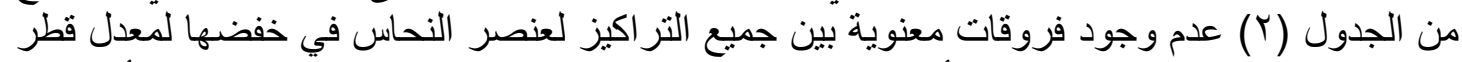

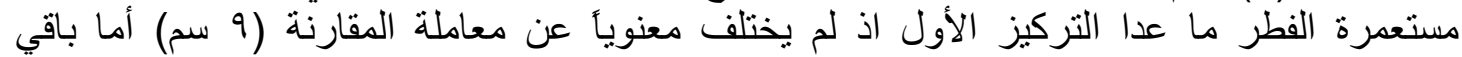

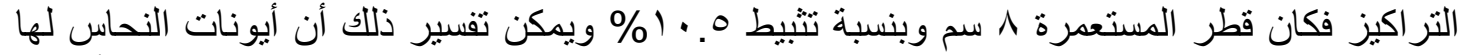

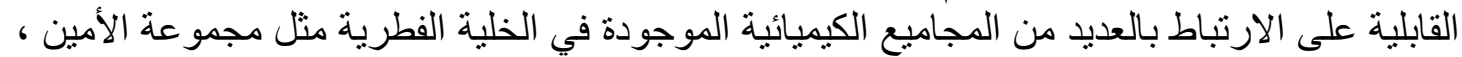

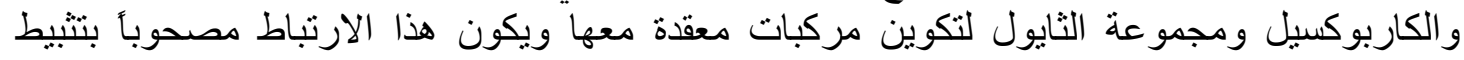

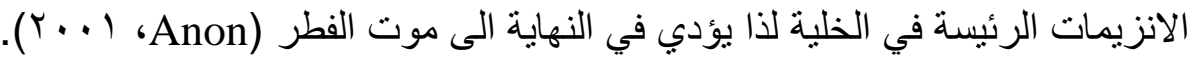

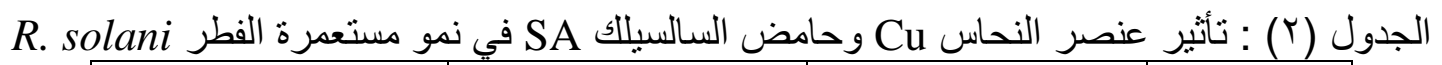

\begin{tabular}{|c|c|c|c|}
\hline \% للتثبيط & قطر المستعمرة (سم) & التر اكيز (ملم / لتر) & المعاملات \\
\hline صفر ب* & 9 & صفر (المقارنة) & \multirow{5}{*}{$\mathrm{Cu}$} \\
\hline صفر ب & 9 & 1 & \\
\hline 11.0 & $\Lambda$ & $r$ & \\
\hline 11.0 & $\Lambda$ & $\mu$ & \\
\hline 11.0 & $\wedge$ & $\varepsilon$ & \\
\hline صفر د & $i v, 0$. & المقارنة & \multirow{5}{*}{ SA } \\
\hline (Y,I & 䧑 & $1 \cdots$ & \\
\hline ب & ج & $r \ldots$ & \\
\hline 101,1 أب & $2 T, 07$ & r.. & \\
\hline I07,V & د, & $\varepsilon \ldots$ & \\
\hline
\end{tabular}

* الأحرف المتشابهة تدل على عدم وجود فروق معنوية بينها عند مستوى احتمال ه. د. دسب اختبار دنكن متعدد

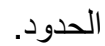

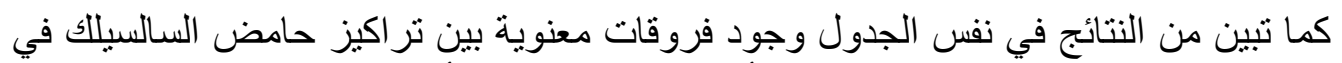

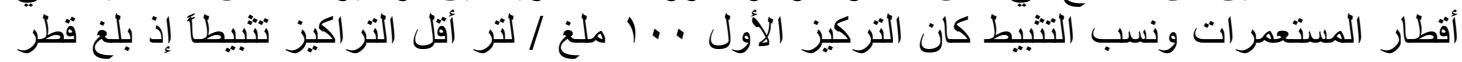

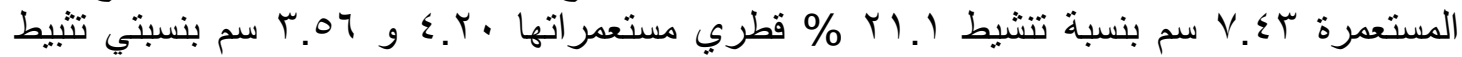

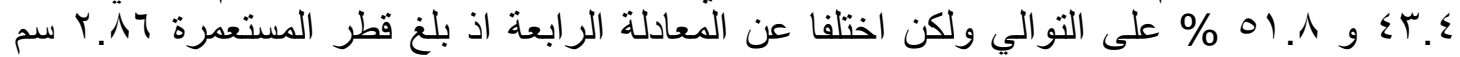

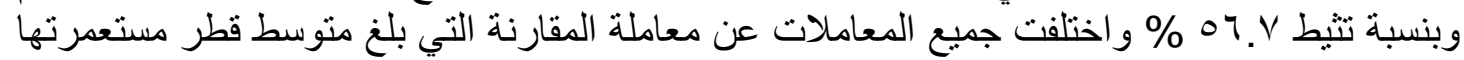

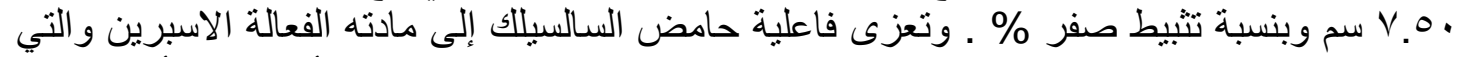

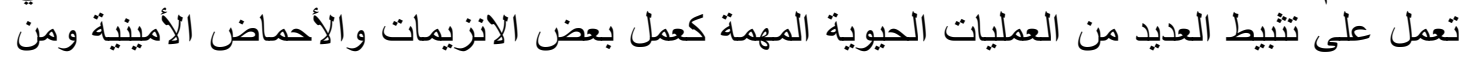

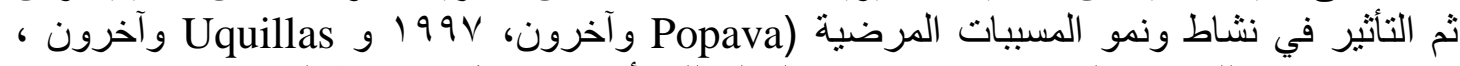

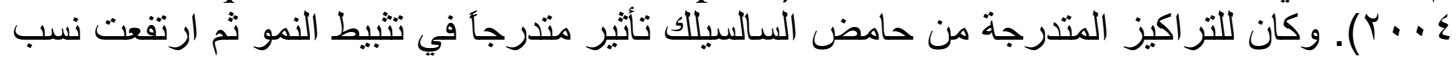

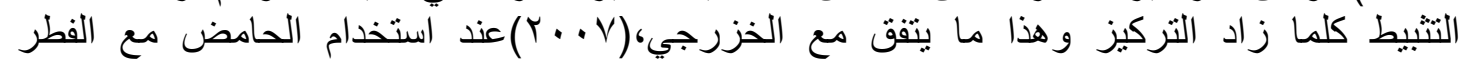
. Pythium aphanidermatum

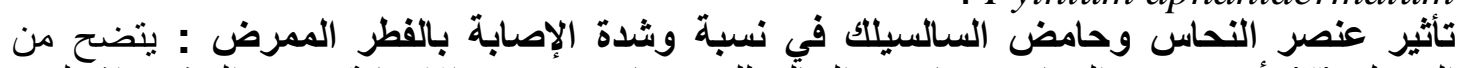

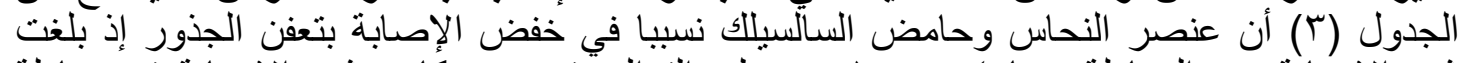

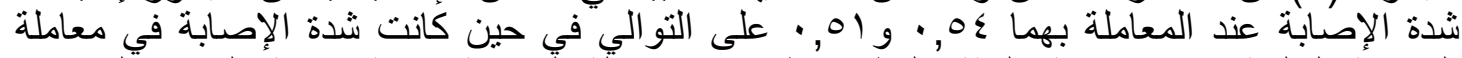

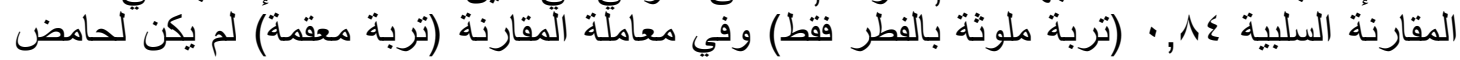




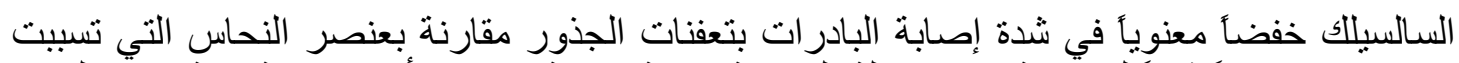

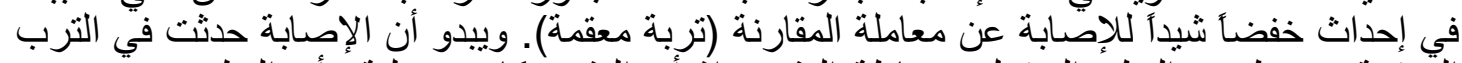

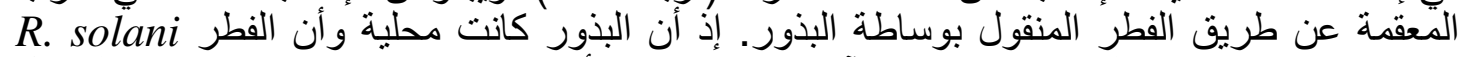

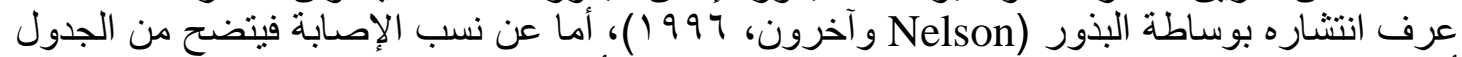

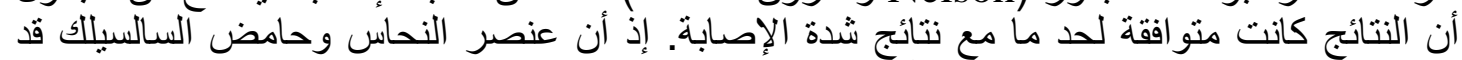

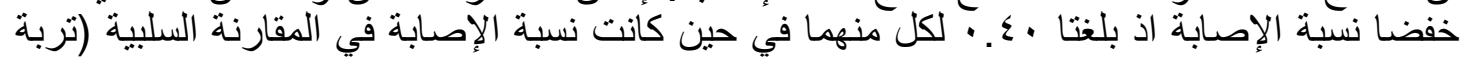

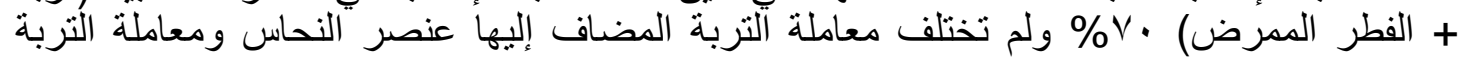

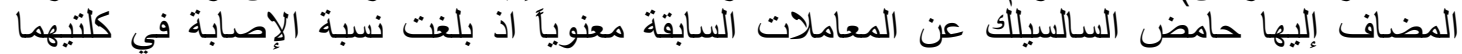

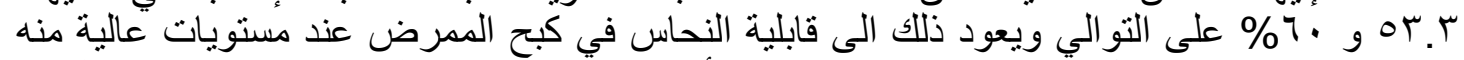

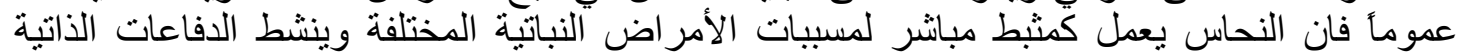

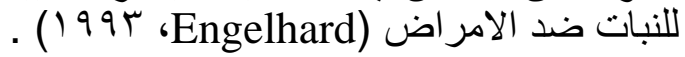

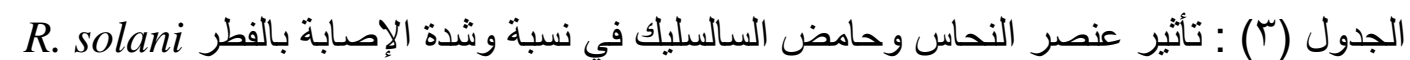

\begin{tabular}{|c|c|c|}
\hline شدة الإصـابة & \% الإصـابة & المعاملات \\
\hline ج:.77 & أب7.7 & مقارنة (تربة معقمة) \\
\hline$I \cdot . \wedge \varepsilon$ & IV. & مقارنة سلبية (تربة + الفطر الممرض) \\
\hline ب & 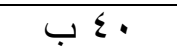 & تربة معقمة \\
\hline 1 & • & SA + تربة معقمة \\
\hline$د \cdot 0 \leqslant$ & آ & تربة + الفطر الممرض + Cu \\
\hline $2 \cdot .01$ & 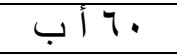 & SA + تربة + الفطر الممرض \\
\hline
\end{tabular}

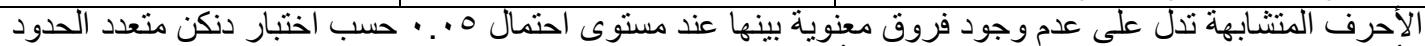

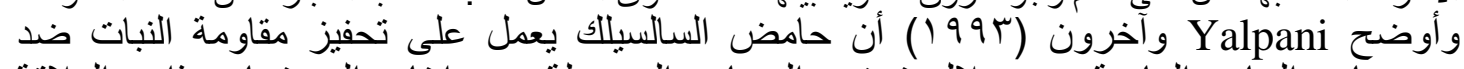

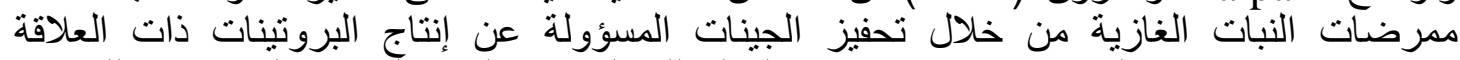

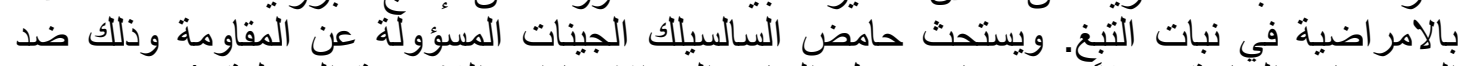

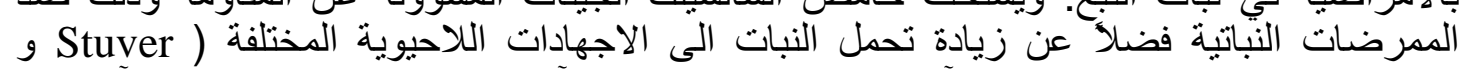

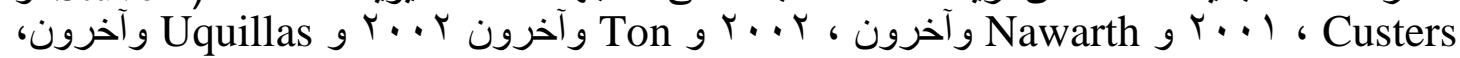

. (r...

\title{
EFFECT OF COPPER AND SALICYLIC ACID IN THE SYSTEMIC RESISTANCE ACQIRED OF BEANS AGAINST Rhizoctonia solani
}

S. Y. Muhammed , N. Y. Al-Morad , H.A. Ahmed

Dept. of Plant Protection, College of Agric and Forestry.

University of Mosul. Iraq

\begin{abstract}
The study conducted to evaluate the systemic resistance of bean seedlings infected with root rot caused by Rhizoctonia solani using nutritional element of copper and Saliycili acid showed that copper is effective in the reduction of the mycelial growth of the fungus that inhibited by $(10.5 \%)$ when used at $4 \mathrm{mg} / \mathrm{ltr}$. The results also provide the effectiveness of Salicylic acid in the reduction of growth rate of the fungus since inhibited by $56.7 \%$ when used in the at $400 \mathrm{mg} / \mathrm{l}$ However copper and salicylic acid led to the reduction of infection severity with Rhizoctonial root rot which reached 0.54 and 0.51 , respectively .
\end{abstract}

\footnotetext{
المصادر

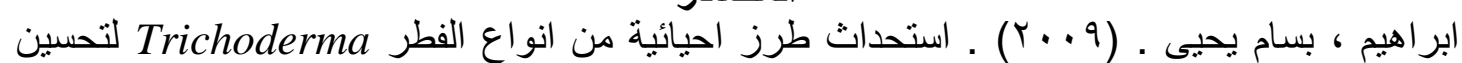

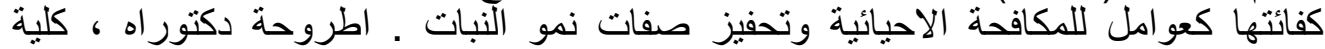

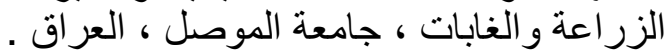




$$
\begin{aligned}
& \text { المجلد (• ع) العدد (1) r r r }
\end{aligned}
$$

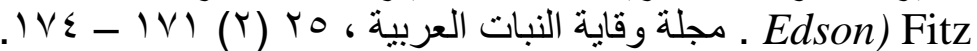

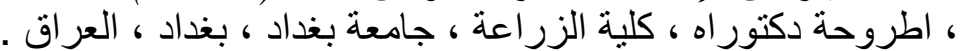

Anonymous (2001). Copper as a beneficial nutrient in agriculture. Agmin Newsletter 221: 1-2.

Engelhard, ed, W. (1993). Soil Borne Plant Pathogens, Management of diseases; with macro and microelements. American Phytopathological Society, Ohio 43160.

Garrett, S.D. (1970). Pathogenic Root Infecting Fungi. Cambridge Univ. Press, Cambridge. 294 pp.

Nawarth, C; S. Heck; N. Parinthawong and J.P. Metranx (2002). EDS5 an essential component of salicylic acid dependent signaling for disease resistance in arabidopsis, is the number of the mate transporter family. Plant Cell 14: 275-286.

Nelson, B.; Helms, T.; Christranson; T. and I. Kural (1996), Characterization and pathogenicity of Rhizoctonia from soybean, Plant Disease. 80: 74-80.

Parmeter, J.R. and H.S. Whitney (1970). Taxonomy and nomenculture of the Imperfect State of Rhizoctonia solani . Biology and Pathology Journal University California, Berkeley Los. P. 7-10.

Papova, L; T Pancheva and A. Uzunova (1997). Salicylic acid: properties, Biosynthesis and physiological Bulgarian Rol. Plant. Physiology Journal. 23 (1-2): 85-93.

Roberts, D.L. and L.J. Herr, (1979). Soil populations of Rhizoctonia solani from areas of healthy and disease beets within four sugar beet field, differing in soil texture. Canadian Journal Microbiology, 25: 902-910.

Stuver, M.H. and J.H.H.V. Custers (2001). Engineering disease resistance in plant. Nature 411: 865-868.

Ton; J., J.A.V. L.C. Pelt; Vanloon and C.M. Pieters (2002). Differential and effectiveness of salicylate -dependent and jasmonate/ethylen induced resistance in arabidopsis Molecular Plant Inetraction. 15: 27-34.

Uquillas, C; I. Letelier; F. Blanco; X. Jordana and L. Holnigne (2004). NPRL - Independent activation of immediate early salicylic acid - responsive genes. Society 17(1): 34-42.

Vanloon, L.C. (1997). Induce resistance in plant and the role of pathogenesis related proteins. European Journal of Plant Pathology. 103: 753-765.

Yalpani, N; V. Shulae and I. Raskin (1993). Endogenous salicylic and levels correlate with accumulation of pathogenesis related proteins and virus resistance in tobacco. Phytopathology 83: 702-708. 